\title{
A referendum on Irish unification: why it needs attention
}

\author{
Alan Renwick and Katy Hayward \\ Political Insight 12, no. 2 (June 2021), pp. 166-19
}

Note: This is the final manuscript copy. Some small changes occurred at the proofing stage. Please check against the published copy before quoting.

A referendum on Irish unification - a so-called 'border poll'-could happen in the coming years. The government in London does not want one, and its Dublin counterpart is decidedly lukewarm. But they may have little choice. Under the terms of Belfast/Good Friday Agreement of 1998-the deal that brought peace to Northern Ireland after thirty years of violence-the Secretary of State for Northern Ireland must call a referendum if they believe a majority for unification is likely.

That condition is not currently met: opinion polls and election results suggest that the majority would still support the Union. This situation might continue, but equally, it might not. Since the UK's decision to leave the EU in 2016, the question of Northern Ireland's status within the Union has risen up the political agenda. The Irish border-whose significance had been declining for two decades-has gained renewed meaning and potency. Some evidence suggests increased support for a united Ireland, though this seems to be mainly among previously 'soft' nationalists rather than from disillusioned unionists or others. The implementation of Brexit has caused considerable disruption and, as riots in loyalist areas in April 2021 showed, deep discontent on both sides of the constitutional divide.

So what would a referendum on the unification question look like? What proposal would be on the ballot paper? Who would be entitled to vote? What parallel process would take place in the Republic of Ireland? How would the form of a united Ireland be worked out? Would such a plan be developed before a referendum or afterwards, in the event that the majority backed change? 
Remarkably, none of these questions have been answered. The 1998 Agreement sets out when a referendum could and must happen, and makes some other important provisions. But on many of the key issues it is silent, or-perhaps deliberately-ambiguous. And no one has ever filled the gaps. For much of the period since 1998, a referendum has seemed a distant prospect, with immediate challenges more pressing. Both governments have had other priorities (not least after the 2008 crash). Neither government wants to be seen to be preparing the ground.

There have been two previous referendums on Northern Ireland's constitutional future. In 1998, voters both north and south of the border voted on the Belfast/Good Friday Agreement. Before that, in 1973, Northern Ireland's voters were asked whether they wanted to remain in the UK or join the Republic of Ireland. But neither vote offers much guiding precedent. In 1998, the proposition on offer was a peace deal on which the British and Irish governments and most political parties in Northern Ireland were united. It pushed the most contentious question - the question of sovereignty-into the distant future. The 1973 vote was on that question, but, with the majority for the Union being then clear, it was called by the UK government as a mechanism for consolidating the status quo. Nationalists boycotted the vote. The Irish government was not directly involved, and plans for a united Ireland were not developed.

So the format of a referendum on the unification question has not been worked out. Yet few electoral events have higher stakes than this one would. The choice presented to the voters would be at the very root of the unionist/nationalist difference and thus inevitably deeply divisive in Northern Ireland. The history of violence serves as a grim reminder of what can happen when that division is handled poorly. The vote, whatever its outcome, would profoundly affect the future of Ireland and the United Kingdom as well. As with any referendum, the design would be crucial for maintaining stability and securing an outcome that could be accepted as legitimate and stand the test of time.

So there is a real gap to be filled. Detailed referendum plans are not needed imminently. But the issues need to be understood, and the design options, along with their strengths and weaknesses, mapped out.

\section{Working Group}


To address this need, the UCL Constitution Unit-which conducts research to inform debates about the design of political institutions in the UK and abroad - teamed up with scholars in Ireland, Northern Ireland, and the United States to establish a Working Group on Unification Referendums on the Island of Ireland. Our group comprises twelve experts in politics, history, sociology and law. We have no collective view on whether there should be a referendum or what the outcome should be if one is ever held. We have come together because we believe these matters require advance thinking. Over the past eighteen months, we have pooled our own diverse expertise and consulted widely among scholars, politicians, former officials, and members of the public. We published an interim report in November 2020, and our final report will come out this summer.

\section{What does the law say?}

The first task of the Working Group was to clarify the existing legal framework. The Belfast/Good Friday Agreement is explicit that unification could not happen without a referendum vote in its favour in Northern Ireland. It requires a democratic process in the Republic of Ireland as well, but is less clear as to the form that might take. We find that a referendum would be required there too, either amending or replacing the Irish Constitution.

The Agreement says that unification requires the support of a majority of those voting. That necessarily means a simple majority: $50 \%+1$ of the votes cast, calculated separately, both north and south. During our work, we have heard various arguments for a higher, supermajority threshold. But that would violate the Agreement. It would also treat the two options on the ballot paper unequally, which would not be defensible. If the simple majority threshold were reached both north and south, unification would then have to take place.

The referendums held north and south of the border would have to be 'concurrent'. In our interpretation, that does not require them to be held simultaneously-though, of course, they could be. But it does mean they would have to be on the same proposal. This is an important constraint. It means, for example, that it would not be possible to first have a vote in Northern Ireland on the principle of unification with the intention that, if voters opted for unification, the details would be worked out afterwards and then put to a vote in the Republic. The requirement of concurrent referendums means at least a minimal degree of coordination between the British and Irish governments. 
This poses practical as well as political challenges, particularly given the British government's role in initiating these processes. It is for the Secretary of State for Northern Ireland to call a referendum. He or she may do so at any time (provided there has been no such vote in the preceding seven years), and must do so 'if at any time it appears likely to him that a majority of those voting' would back unification.

\section{Calling a referendum}

This final point leads to the question of how the Secretary of State should gauge how people would likely vote in a referendum. On this, the Agreement is silent, but it is a crucial matter. The requirement is to assess likely voting patterns in a future, hypothetical vote. This is an extremely difficult task at the best of times and on the most mundane of topics. In this case, it would have to be done before campaigning commenced, and at a point when many people might not have focused their minds on the matter. This judgement might have to be made before detailed proposals for a united Ireland had been developed.

This is one reason why, though the Irish government has no formal role, coordination between the two governments would be highly desirable. Another way of reducing the breadth and impact of the many 'known unknowns' in this case would be to decide in advance what factors may inform the Secretary of State's decision. Various sources of evidence-notably including opinion polls and surveys, election results, and any votes held on the matter in the Northern Ireland Assembly - would need to be given due consideration. No rigid formula could be applied to the interpretation of such evidence-a contextual judgment would be required. It is worth recalling, too, that the British government is required by the 1998 Agreement to exercise its power in Northern Ireland with 'rigorous impartiality'. This will remain imperative.

\section{Referendum configurations}

The most complicated question concerns how the referendums north and south would best be configured as part of the overall decision-making process. In particular, would referendums come early in that process, before detailed plans for a united Ireland had been worked out? Or would they come later, so that voters could go to the polling station knowing exactly what each option on the ballot paper would mean? 
One of the most frequent refrains we have heard during our research is that lessons from the Brexit process should be learned. What people of all political persuasions want to avoid is a referendum being called with no plan in place for what would ensue if voters opted for unification. In the case of Brexit, there was minimal planning for what leaving the European Union would actually look like. This is widely seen as having contributed to the political tension and frequent gridlock in Westminster post-2016. Allowing similar uncertainties in the context of Northern Ireland could be dangerous.

Another possible approach that we looked at carefully but ultimate rejected was a two-stage referendum: a vote first on whether to enter detailed negotiations, followed by a second vote on whether to go for unification on the proposed terms. Similar two-stage processes have long been advocated by Constitution Unit scholars in other contexts, but this would not be tenable in Northern Ireland. The 1998 Agreement stipulates that one referendum vote, held both north and south, is sufficient for unification to be required.

In the end, we suggest that three referendum configurations deserve further consideration. In the first, a single referendum (north and south) would take place late in the process, once as much as possible of the form of a united Ireland had been agreed. In the other two, the key referendum would take place earlier: voters would be offered both the principle of unification and a plan for the process through which the final form of a united Ireland would be agreed. The difference between these latter two configurations rests on the point at which the permanent form of a united Ireland would be worked out: either before the transfer of sovereignty from London to Dublin, or afterwards. In either case, default and/or interim arrangements would be needed while the details were worked out, and in case agreement on them could not be reached.

The main advantage of the first configuration is that it would maximise voters' ability to make an informed choice because much of the shape of a united Ireland would be known at the time of the vote. The main disadvantage is that it may be impossible to include all perspectives in designing the proposed new Ireland. This is particularly true because it may be presumed that, as long as they are seeking to maintain the status quo, few unionists would take part in processes intended to draw up proposals for a united Ireland. The second two configurations would more or less reverse that equation: voters' choice would be less informed because the united Ireland would only be designed after a 
vote in favour of unification unification; but the design process itself might be more inclusive of all perspectives.

\section{Campaign conduct rules}

One further crucial aspect of any future referendum would be the conduct rules for the campaign. Social media are already being used to mobilise people around the issue of a potential border poll (both for and against). But existing campaign rules in both the UK and Ireland are badly out of date in the digital age, and urgently need to be strengthened. They fail to provide adequate protections against misinformation or unfair campaign spending, and do little-particularly in the UK-to help voters access the information they want from sources they trust. There are also differences in campaign spending rules between the two jurisdictions that could cause trouble in the context of concurrent votes on both sides of the border. For instance, Ireland caps campaign donations but not spending; the UK does the reverse.

\section{Conclusion}

Given all the complexities just set out, perhaps our most important conclusion is that it would be highly unwise for referendums north and south to be called without a clear plan for the referendums themselves and the other associated processes. Otherwise, uncertainties and unrealistic expectations-about timings, sequencing, and other matters-could generate severe difficulties further down the road. Moreover, because some related decisions (such as on the franchise and campaign rules) could potentially affect the outcome, it would be prudent to make them at a time when they feel 'academic' rather than necessary and urgent. We do not say when planning should begin, not least because that is a political matter. However, we are clear that planning around referendums on Irish unification would need to take place in advance of any being called.

The British-Irish intergovernmental relationship underpinned the 1998 Agreement, and it will remain of vital importance regardless of continuity and change in the constitutional status of Northern Ireland. Any future referendums on Irish unification would transform both countries, and planning for such an eventuality is a shared concern. It is a necessary duty of public authorities to plan well, even for those events they may dread the most. There will never be a time in which planning for a border poll will not be controversial 
or arduous. There may, possibly, come a time when it will be too late to do it as carefully as required.

Alan Renwick is Deputy Director at the Constitution Unit, University College London. Katy Hayward is Professor of Political Sociology at Queen's University Belfast. More information on the Working Group on Unification Referendums, including the interim report, can be found here. 